\title{
Perancangan E-Recruitment Dosen Baru Berbasis Web Dengan Metode Design Sprint
}

\author{
Ahmad Chusyairi ${ }^{1{ }^{\star}}$, Samhana Suryati Subari ${ }^{1}$ \\ ${ }^{1}$ Teknik Informatika; Fakultas Informatika; Universitas Bina Insani; Jl. Raya Siliwangi No.6 \\ Rawa Panjang Kota Bekasi, 02182436886; e-mail: ahmadchusyairi@binainsani.ac.id, \\ hana.samhana@gmail.com \\ * Korespondensi: e-mail: ahmadchusyairi@binainsani.ac.id
}

Diterima: 7 Oktober 2020; Review: 12 Oktober 2020; Disetujui: 18 Oktober 2020;

Cara sitasi: Chusyairi A, Subari SS. 2020. Perancangan E-Rekruitment Dosen Baru Berbasis Web Dengan Metode Design Sprint. Informatics for Educators and Professionals. 5 (1): 11-22.

\begin{abstract}
Abstrak: Perekrutan dosen baru pada Universitas Bina Insani adalah upaya dari bidang sumber daya manusia untuk memenuhi kebutuhan dalam pendidikan, penelitian dan pengabdian kepada masyarakat, sehingga Tri Dharma Perguruan Tinggi dapat berjalan baik. Calon dosen baru dapat melihat informasi berupa pengumuman, periode lowongan dan memasukkan biodata diri, upload dokumen, pendidikan baik formal (sarjana, magister dan doktor) maupun non formal (kursus bahasa, kursus keahlian, tes potensi akademis, TOEIC/TOEFL/IELTS), pengalaman dalam mengajar institusi dalam negeri dan luar negeri, penelitian, publikasi jurnal, pertemuan ilmiah, pengabdian masyarakat, penghargaan, pengalaman kerja, pengalaman organisasi, lamaran dan register. Untuk dapat mempermudah proses perekrutan dosen baru, maka diperlukan Perancangan E-Recruitment Dosen Baru Berbasis Web. Metode yang digunakan dalam penelitian ini adalah design sprint yang terdiri dari tahapan understanding, diverage, decide, prototype dan validate. Kesimpulan yang didapatkan dalam penelitian ini adalah kemudahan dalam perekrutan dosen baru untuk ditempatkan pada program studi: S1Teknik Informatika, S1-Sistem Informasi, S1-Rekayasa Perangkat Lunak, S1-Akuntansi, S1Manajemen, D3-Manajemen Informatika, D3-Akuntansi, D3-Manajemen Administrasi, dan D3Sekretari yang ada di Universitas Bina Insani.
\end{abstract}

Kata Kunci: Dosen Baru, Design Sprint, E-Recruitment, Tri Dharma Perguruan Tinggi, Web

\begin{abstract}
The recruitment of new lecturers at Bina Insani University is an effort from the field of human resources to meet the needs in education, research and community service, so that the Tri Dharma of Higher Education can run well. Prospective new lecturers can view information in the form of announcements, vacancy periods and enter personal data, upload documents, formal (bachelor, master and doctoral) and non-formal education (language courses, skills courses, academic potential tests, TOEIC/TOEFL/IELTS), experience in teaching domestic and foreign institutions, research, journal publications, scientific meetings, community service, awards, work experience, organizational experience, applications and registers. In order to simplify the process of recruiting new lecturers, a Web-based E-Recruitment Design is needed. The method used in this study is a design sprint consisting of stages of understanding, leverage, decide, prototype and validate. The conclusion obtained in this study is the ease in recruiting new lecturers to be placed in study programs: S1-Informatics Engineering, S1Information Systems, S1-Software Engineering, S1-Accounting, S1-Management, D3Management Informatics, D3-Accounting. , D3-Administrative Management, and D3-Secretarial at Bina Insani University.
\end{abstract}

Keywords: New Lecturer, Design Sprint, E-Recruitment, The Threefold Missions of Higher Education, Web 


\section{Pendahuluan}

Dosen adalah pendidik profesional dan ilmuwan dengan tugas utama mentransformasikan, mengembangkan, dan menyebarluaskan ilmu pengetahuan, teknologi, dan seni melalui pendidikan, penelitian, dan pengabdian kepada masyarakat. (PP No. 37, 2009). Pengangkatan dan penempatan seorang dosen yang diangkat oleh penyelenggara pendidikan tinggi atau satuan pendidikan tinggi yang diselenggarakan masyarakat dilakukan berdasarkan perjanjian kerja atau kesepakatan kerja bersama. Untuk mendapatkan dosen yang berkualitas dibutuhkan kualifikasi dan kriteria yang tinggi baik sehat jasmani maupun rohani dalam proses seleksi penerimaannya serta harus memiliki kemampuan untuk mewujudkan tujuan pendidikan nasional. Dosen tetap adalah dosen yang bekerja penuh waktu yang berstatus sebagai tenaga pendidik tetap pada satuan pendidikan tinggi tertentu (PP No. 37, 2009) berdasarkan perjanjian kerja atau kesepakatan kerja bersama yang tertulis antara dosen dengan penyelenggara pendidikan tinggi atau Satuan Pendidikan Tinggi yang memuat syaratsyarat kerja serta hak dan kewajiban para pihak dengan prinsip kesetaraan dan kesejawatan berdasarkan peraturan perundang-undangan yang berlaku. Untuk mendapatkan dosen yang tepat dibutuhkan kualifikasi yang tepat diantaranya paling utama adalah kualifikasi pendidikan melalui ijazah dengan gelar megister atau sering disebut S2 atau doktoral (S3) dan kemampuan akademik serta kemampuan psikotesnya [5].

Dalam mewujudkan visi dan misi STMIK SZ NW Anjani selalu berupaya meningkatkan mutu atau kualitas internal secara berkelanjutan sebagai starategi institusi untuk dapat bersaing dengan perguruan tinggi lain. Salah satu cara untuk meningkatkan mutu dari suatu perguruan tinggi adalah dengan meyeleksi tenaga pengajar atau dosen, karena kualitas dosen akan sangat menentukan tinggi dan rendahnya kualitas suatu perguruan tinggi [1].

STMIK Amik Amik Riau merupakan sebuah lembaga pendidikan tinggi yang fokus pada ilmu komputer, dalam proses pembelajaran dibutuhkan dosen dengan kualifikasi terbaik, untuk mendapatkan dosen dengan kualifikasi terbaik tersebut diperlukan rangkaian proses seleksi yang objektif, dan sebuah sistem dapat dibangun untuk digunakan didalam proses seleksi ini, sistem yang dibangun menggunakan metode multi atribut utility theory, metode multi atribut utility theory akan digunakan untuk mengolah kriteria yang telah ditentukan sebelumnya, dan kriteria inilah yang akan diolah menjadi sebuah rekomendasi. Metode multi atribut utility theory digunakan untuk membandingkan nilai kuantitatif yang mengkombinasikan pengukuran dari nilai-nilai yang ada. Metode multi atribut utility theory juga digunakan untuk merubah dari beberapa kriteria kedalam nilai numerik. Penulis menargetkan sistem ini mampu memberikan solusi dari masalah yang ada dan memberikan rekomendasi kepada pimpinan dalam menentukan keputusan [2].

Untuk menjadikan mahasiswa dan lulusan sarjana yang berkualitas tentu dibutuhkan pengajar yang kompeten dibidangnya. Untuk menyelesaikan berbagai masalah di atas, maka salah satu langkah yang bisa kita ambil dalam membuat keputusan adalah dengan menggunakan metode AHP (Analytic Hierarchy Process). Dari latar belakang diatas dapat disimpulkan bahwa pengajar yang berkualitas dapat menghasilkan mahasiswa yang berkualitas pula [3].

Proses penerimaan dosen di Universitas Islam Raden Rahmat Malang selama ini masih tidak obyektif dikarenakan hanya proses wawancara dan berkas pelamar saja yang dipertimbangkan tanpa adanya proses lainnya. Hal itu menyebabkan tidak tepatnya pemilihan dosen yang diterima dan ketidaksesuaiannya antara ilmu yang dikuasai dengan materi yang diajarkan, sehingga hal tersebut dapat mempengaruhi daya serap mahasiswa terhadap mata kuliah yang diajarkan oleh dosen tersebut. Oleh karena itu untuk mengoptimalkan proses penilaian kompetensi atau potensi dari dosen pelamar yang ada, perlu dibangun sebuah sistem berbasis komputer yang dinamakan sistem pendukung keputusan, dengan menggunakan metode yang sesuai yaitu profile matching agar dapat memberikan suatu hasil penilaian yang objektif untuk menghasilkan dosen baru yang mempunyai kompetensi dan kualitas yang baik. Permasalahan tersebut yang menjadi landasan peneliti untuk mengembangkan sistem pendukung keputusan menggunakan metode profile matching di Universitas Islam Raden Rahmat Malang. Penerapan sistem pendukung keputusan menggunakan metode profile matching akan membantu tim penyeleksi dalam menentukan dosen baru yang akan diterima. Sistem pendukung keputusan ini akan mendukung keputusan yang akan diambil oleh tim penyeleksi [4]. 
Proses penerimaan calon dosen merupakan proses recruitment calon dosen di perguruan tinggi untuk mendapatkan dosen yang sesuai dengan kriteria yang telah ditentukan oleh masing-masing instansi. Dalam merekrut dosen bukanlah hal yang mudah dilakukan di STMIK Amikom Yogyakarta, dosen yang dipilih haruslah calon dosen yang memenuhi kriteria yang ditentukan oleh STMIK Amikom Yogyakarta. Untuk itu calon dosen tetap harus melewati beberapa tes yang harus dilalui terlebih dahulu. Terdapat 2 tahapan tes yang harus dilalui untuk menjadi dosen di STMIK Amikom Yogyakarta yaitu tes microteaching dan tes psikotes. Dari masing-masing tahapan seleksi terdapat sub-sub kriteria untuk menjadi bahan pertimbangan dalam proses penilaian lulus atau tidak calon dosen tersebut. Calon dosen yang lulus seleksi tahap pertama yaitu tes microteaching, maka berhak mengikuti tes tahap kedua yaitu tes psikotes. Proses seleksi penerimaan calon dosen yang dilakukan saat ini masih bersifat subyektif, sehingga menimbulkan banyak keputusan dengan tingkat subyektifitas yang tinggi. Tingkat subyektifitas yang dilakukan tidak menggunakan kriteria yang sudah ditentukan, untuk itu perlu adanya sistem yang dapat membantu merekomendasikan calon dosen di STMIK AMIKOM Yogyakarta [6].

Rekrutmen merupakan langkah awal yang dilakukan oleh Universitas Muhammadiyah Riau (UMRI), guna menjaring calon tenaga kerja yang professional. Profesionalitas dibutuhkan sebagai salah satu input bagi lembaga pendidikan Muhammadiyah untuk menghasilkan output yang sesuai dengan visi dan misi lembaga pendidikan Muhammadiyah. UMRI sebagai Amal Usaha Muhammadiyah (AUM) dibidang pendidikan perlu melakukan beberapa upaya untuk bisa mendapatkan calon pegawai dan dosen yang professional. Seiring perkembangan ilmu pengetahuan dan teknologi, UMRI perlu mengimplementasikan Erecruitment sebagai salah satu teknologi yang bisa digunakan untuk menjaring pegawai dan dosen yang profesional [7].

Design Sprint merupakan metodologi desain yang dikembangkan oleh Google untuk menyelesaikan masalah dengan melibatkan pengguna melalui perancangan, pembuatan prototype, dan pengujian ide dengan cepat. Design Sprint juga dapat diartikan sebagai metode untuk membuat suatu produk yang baru. Pada penelitian ini akan menghasilkan suatu tampilan user interface dari aplikasi mobile EzyPay, sehingga metode design sprint terhadap penelitian ini dapat berarti membuat suatu solusi user interface pada kasus aplikasi mobile EzyPay [8].

Design sprint adalah sebuah metodologi yang dapat merancang dan membangun aplikasi dengan cepat dan mudah. Terdapat enam tahap dalam melakukan metode design sprint ini, yaitu: 1. Understand: pada tahap ini ditentukan apa kebutuhan pengguna dan teknologi apa yang cocok untuk diimplementasikan. Ditahap ini dilakukan observasi terhadap pengguna tentang masalah yang terjadi pada pengguna dan penting memahami apa yang dialami oleh pengguna. 2. Define: setelah melakukan tahap understand, selanjutnya menentukan solusi dari permasalahan yang dialami oleh pengguna. 3. Diverge: sebelum melaksanakan tahap decide dilakukan tahap diverge terlebih dahulu dimana pada tahap ini dikembangkan lebih dalam dari solusi yang dibuat, dan memprediksi masalah apa yang akan muncul pada solusi tersebut. 4. Decide: pada tahap ini ditentukanlah solusi yang tepat dari permasalahan yang terjadi. Penentuan solusi dipilih melalui voting atau pemungutan suara. 5 . Prototype: selanjutnya membuat suatu bentuk fisik dari suatu ide atau solusi yang dipilih baik berupa catatan yang dipasang di dinding, objek, atau storyboard. 6. Validate: pada tahap terakhir ini dilakukan uji coba kepada pengguna dari protoype yang dibuat., Pengujian ini selain ditujukan untuk pengguna bisa juga ditujukan untuk stakeholder atau seseorang yang ahli pada bidang tertentu [11].

Web adalah salah satu media yang memudahkan pengguna dalam menyajikan informasi yang berkualitas, sehingga informasi menjadi lebih akurat, relevan dan tepat waktu. Salah satu framework yang memudahkan dalam pembuatan aplikasi web adalah framework Codeigniter dengan konsep MVC [13]. Model dibuat sebelum memisahkan view untuk mendapatkan informasi yang akan ditampilkan [14]. Penggunaan metode MVC (Model-ViewController) dapat mempermudah dalam pembuatan web tentang inovasi pelayanan publik dari Polres Banyuwangi, karena terjadi pemisahan data (Model) dari tampilan (View) dan cara memproses datanya (Controller), sehingga penggunaan kode dapat berkurang secara signifikan, meningkatkan fleksibilitas dan modularitas sistem [15]. 
Bidang sumber daya manusia melalukan perekrutan dosen baru dalam pemenuhan kebutuhan untuk Tri Dharma Perguruan Tinggi yang terdiri dari dalam pendidikan, penelitian dan pengabdian kepada masyarakat dapat berjalan baik. Calon dosen baru dapat melihat informasi berupa pengumuman, periode lowongan dan dapat memasukkan biodata diri, upload dokumen, pendidikan baik formal maupun non formal, pengalaman, lamaran dan register. Untuk dapat mempermudah proses perekrutan dosen baru, maka diperlukan Perancangan ERecruitment Dosen Baru Berbasis Web.

\section{Metode Penelitian}

Metode yang digunakan dalam penelitian ini adalah Design Sprint [9], yang terdiri dari dari tahapan sebagai berikut: a) Understand, tahapan ini adalah melakukan wawancara dengan bidang Sumber Daya Manusia atau Ketenagaan Universitas Bina Insani mengenai perekrutan dosen baru berdasarkan Buku Pedoman Sumber Daya Manusia. b) Define, melakukan identifikasi kebutuhan mengenai perekrutan dosen baru dari hasil wawancara dengan bidang ketenagaan Universitas Bina Insani. c) Diverage, tahap ini merupakan hasil brainstorming dari hasil tahap define dengan menggunakan teknik Creative Problem Solving (CPS). Prinsip dasar dari metode ini adalah membantu mendefinisikan masalah mengenai perekrutan dosen baru dan peluang yang dihadapi untuk menghasilkan solusi baru yang inovatif berupa e-recruitment. Maksud dari rumus tersebut adalah proses kreatif dihasilkan berupa e-recriutment dari fungsi pengetahuan, daya imajinasi dan evaluasi mengenai perekrutan dosen baru. Pemecahan masalah perekrutan dosen dengan metode CPS telah berubah dan berkembang melalui penelitian, pengembangan dan pelatihan yang berkaitan dengan CPS yang terdiri dari 4 tahap: clarify, ideate, develop dan implement. d) Decide, tahap untuk menjalankan keputusan mengenai e-recruitment dengan memilih ide terbaik dari hasil diverage dengan berdiskusi dengan tim, membuat story board dan memutuskan yang terbaik mengenai perekrutan dosen baru. e) Prototype, tahap ini adalah implementasi ide mengenai e-recruitment yang telah diputuskan untuk dimasukkan dalam sistem untuk perbaikan dengan memasukkan kebutuhan user (bidang ketenagaan Unversitas Bina Insani). Prototype yang dibuat meliputi 2 hal, yaitu: vertical prototyping dan horizontal prototyping. Vertical prototyping adalah jumlah fitur dari sistem e-recruitment dikurangi. Horizontal prototyping adalah tingkat fungsi dari sistem $e$ recruitment dikurangi jadi tampilan antar muka (framework). f) Validate, adalah tahap akhir dengan menguji prototipe e-recruitment yang dibuat. Uji prototipe e-recruitment dilakukan dengan melibatkan user (bidang ketenagaan Universitas Bina Insani) dan analisis dengan usability teknik Bevan dan Mcleod yang meliputi 3 hal yaitu effectiveness (efektif), efficiency (efisien) dan satisfaction (kepuasan) mengenai e-recruitment.

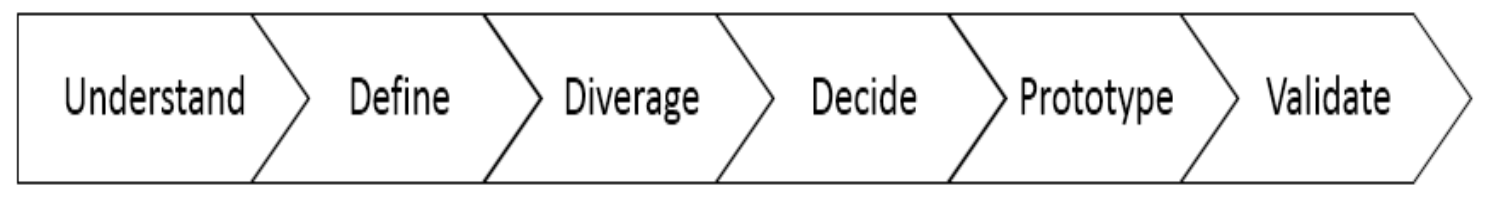

Sumber: Hasil Penelitian (2020)

Gambar 1. Tahapan Design Sprint [10]

\section{Hasil dan Pembahasan}

Hasil dan pembahasan dalam penelitian ini adalah sebagai berikut : Understand, dengan melakukan wawancara dengan bidang Sumber Daya Manusia atau Ketenagaan Universitas Bina Insani mengenai perekrutan dosen baru berdasarkan Surat Keputusan Rektor Nomor 035/BiU/1.4/l/2020 tentang Buku Pedoman Sumber Daya Manusia yang ditetapkan di Bekas pada tanggal 24 Januari 2020 oleh Rektor Universitas Bina Insani: Dr. Indra Muis, S.S., M.M yang dijelaskan pada gambar 2. Persyaratan Administratif bagi setiap pelamar wajib mengajukan lamaran secara tertulis yang diajukan kepada Rektor BiU melalui Kepala Biro Ketenagaan BiU dengan dilengkapi persyaratan administratif yang terdiri atas: 1) Riwayat hidup, 2) Fotokopi ijazah dan transkrip nilai yang telah dilegalisir (cap basah) oleh instansi yang berwenang, 3) Fotocopy sertifikat kursus/pelatihan/seminar yang pernah diikuti serta hasil karya yang dipublikasikan/dipatenkan bagi dosen, dan ijazah SLTA dan dengan pendidikan selanjutnya serta sertifikat kursus/pelatihan yang pernah diikuti bagi Tenaga Kependidikan, 4) ljazah lulusan luar negeri harus mendapatkan pengesahan dari Kementerian Pendidikan dan 
Kebudayaan Republik Indonesia, 5) Surat Keterangan Catatan Kepolisian (SKCK) yang masih berlaku, 6). Pasfoto terakhir berwarna, ukuran $4 \times 6 \mathrm{~cm}$, 3 (tiga) lembar, 7) Fotokofi Kartu Tanda penduduk (KTP) dan Kartu Keluarga (KK), 8) Surat Keterangan lolos butuh bagi pelamar yang masih mempunyai ikatan kerja dengan instansi lain, apabila sudah diterima di Universitas Bina Insani, 9) Bukti pengalaman kerja/mengajar dari instansi/Perguruan Tinggi sebelumnya (jika ada), 10) Bukti keputusan penetapan Nomor Registrasi Dosen dan jabatan fungsional akademik bagi Calon Dosen (jika ada), 11) Referensi yang terkait dengan kemampuan akademik maupun kinerjanya, dari 2 (dua) orang (jika ada), 12) Surat keterangan sehat dari Dokter, dan 13) Lebih disukai yang memiliki bukti kemampuan berbahasa Inggris dengan nilai TOEFL minimal 500/setara yang masih berlaku bagi calon Dosen. Aturan recruitment juga telah tercantum dalam Buku Pedoman Sumber Daya Manusia.

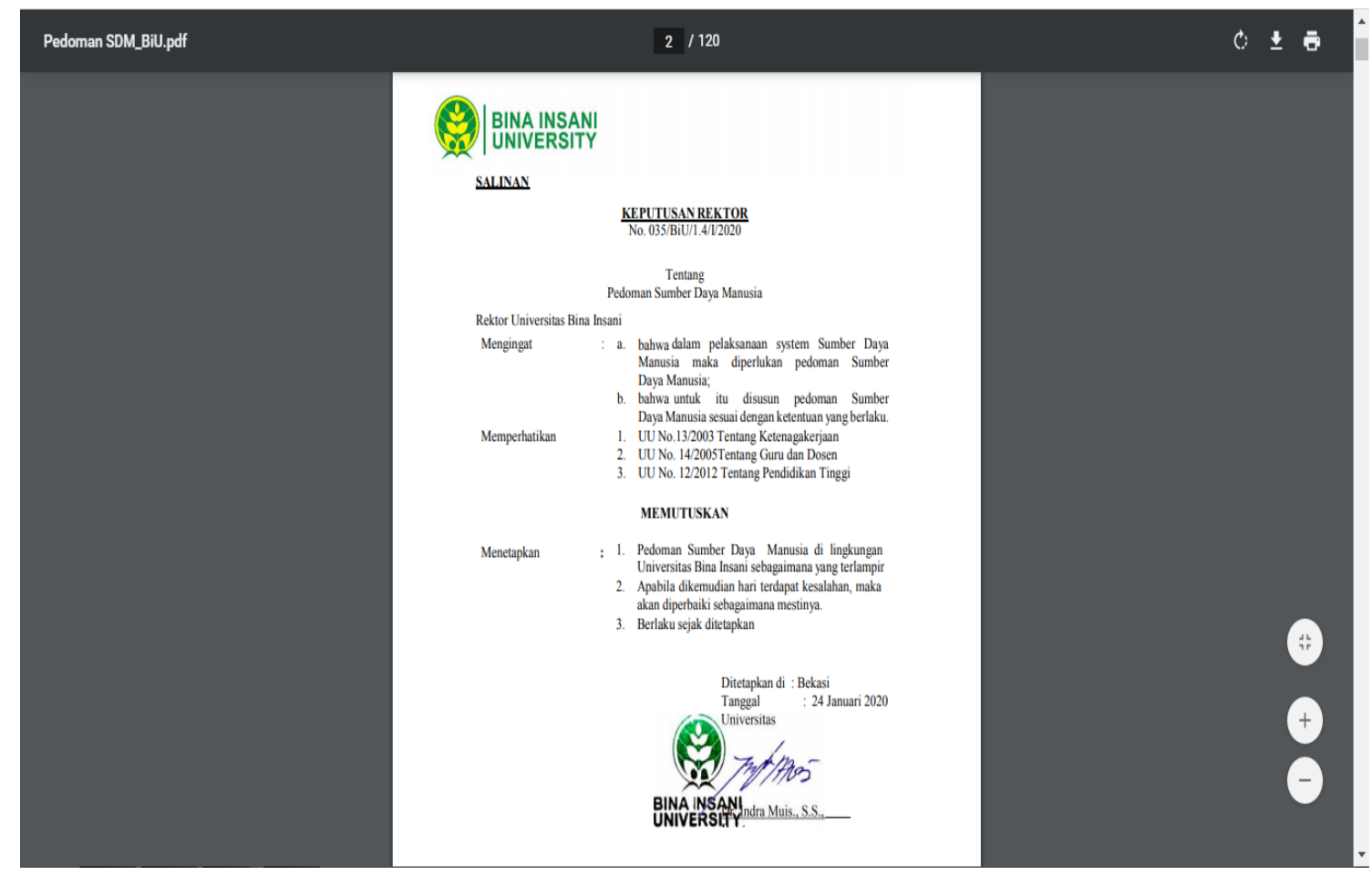

Sumber: Hasil Penelitian (2020)

Gambar 2. Buku Pedoman Sumber Daya Manusia [12]

Define, dengan melakukan identifikasi kebutuhan mengenai perekrutan dosen baru dari hasil wawancara dengan bidang ketenagaan Universitas Bina Insani yang berupa pengumuman, periode lowongan dan memasukkan biodata diri, upload dokumen, pendidikan baik formal maupun non formal, pengalaman, lamaran dan register. Persyaratan khusus pada rekrutmen Dosen Tetap adalah: 1) Berijazah serendah-rendahnya S-2/Sp1 dengan IPK $\geq 3,00$ untuk mengajar Pada Program Sarjana dan Program Vokasi, 2) Berasal dari Perguruan Tinggi yang terakreditasi "A" atau "B" dari disiplin ilmu yang sesuai dengan program yang dikembangkan oleh masing masing Program Studi di Universitas Bina Insani, 3) Usia maksimum 50 (lima puluh) tahun, 4) Usia maksimum 65 (enam puluh lima) tahun bagi yang memiliki jabatan fungsional akademik Guru Besar, 5) Lebih disukai yang memiliki bukti kemampuan berbahasa Inggris dengan nilai TOEFL minimal 500/setara yang masih berlaku bagi calon Dosen.

Diverage, pada tahap ini merupakan hasil brainstorming dari hasil tahap define dengan menggunakan teknik Creative Problem Solving (CPS) yang terdiri dari 4 tahap: 1) Clarify: identifikasi tantangan bidang ketenagaan Universitas Bina Insani mengenai perekrutan dosen baru. Dosen Tetap adalah Karyawan BiU yang dipekerjakan pada Program Studi Strata Satu dan Program Diploma yang mempunyai tugas melaksanakan Pendidikan dan Pengajaran, Penelitian dan Pengembangan IImu, Pengabdian Kepada Masyarakat, Administrasi dan Manajemen serta Pembinaan Civitas Akademika dengan beban tugas Program Proposional 12 sks, 2) Ideate: menghasilkan ide berupa e-recruitment, 3) Develop: membawa e-recruitment 
untuk dapat diterapkan dalam ke sistem informasi dan 4) Implement: memberikan ide dalam pembuatan e-recruitment. Persyaratan Alih Status Alih status menjadi Dosen Tetap Persyaratan alih status dari Tenaga Kependidikan/Dosen Tidak Tetap dan untuk menjadi Dosen Tetap, sebagai berikut: 1) Mengajukan permohonan alih status kepada Ketua Jurusan untuk diteruskan kepada Rektor Universitas Bina Insani, 2) Mempunyai pengalaman mengajar di Universitas Bina Insani sekurangkurangnya 2 (dua) tahun, 3) Berijazah serendah-rendahnya S2/Sp. 1 dengan IPK minimum $\geq 3,00$ dalam bidang ilmu terkait dengan pengembangan program studi, dari Perguruan Tinggi yang terakreditasi minimum "B" oleh Badan Akreditasi Nasional Universitas Bina Insani (BAN-PT), 4) Mata kuliah yang diasuh adalah Mata Kuliah Dasar Keahlian atau Mata Kuliah Keahlian (bukan mata kuliah Pengembangan Kepribadian), 5) Usia maksimum 50 (enam puluh) tahun, 6) Memperoleh Indeks Penilaian Kinerja sekurangkurangnya rata-rata "BAIK" dalam 2 (dua) tahun terakhir, 7) Mempunyai motivasi dan minat yang Tinggi dalam mengabdikan ilmunya terhadap dunia Pendidikan, 8) Mempunyai intergritas moral dan bertangung jawab terhadap pelaksanaan Tridarma Perguruan Tinggi, 9) Memiliki tata krama dalam pelaksanaan tugas dan tata pergaulan kampus sesuai dengan Nilai-nilai luhur Universitas Bina Insani, 10) Sehat jasmani dan rohani, 11) Lebih disukai yang memiliki Bukti kemampuan berbahasa Inggris dengan nilai TOEFL minimum 500/setara yang masih berlaku, 12) Lulus dalam proses seleksi, 13) Alih status menjadi Tenaga Kependidikan, 14) Mengajukan permohonan alih status kepada Ketua Jurusan untuk diteruskan kepada Rektor Universitas Bina Insani, 15) Usia maksimum 50 (lima puluh lima) tahun, 16) Memenuhi kualifikasi dan kompetensi untuk menjadi Tenaga Kependidikan dalam bidang yang bersangkutan, 17) Memperoleh indeks penilaian kinerja sekurang-kurangnya rata-rata "BAIK" dalam 2 (dua) tahun terakhir, dan 18) Sehat Jasmani dan rohani.

Decide, tahap untuk menjalankan keputusan mengenai e-recruitment dengan memilih ide terbaik dari hasil diverage dengan berdiskusi dengan tim, membuat story board dan memutuskan yang terbaik mengenai perekrutan dosen baru pada: 1) Fakultas Informatika: Sistem Informasi Program Sarjana, Teknik Informatika Program Sarjana, Rekayasa Perangkat Lunak Program Sarjana, dan Manajemen Informatika Program Diploma Tiga, 2) Fakultas Bisnis: Manajemen Program Sarjana, Akuntansi Program Sarjana, Manajamen Administrasi Program Diploma Tiga, Sekretari Program Diploma Tiga dan Akuntansi Program Diploma Tiga.

Prototype, pada halaman utama e-recruitment terdapat menu-menu, diantaranya: 1) Home, 2) Pengumuman, 3) Periode Lowongan, 4) Biodata Diri, 5) Upload Dokumen, 6) Pendidikan, 7) Pengalaman, 8) Lamaran, 9) Register, dan 10) Profil yang dijelaskan pada gambar 3.

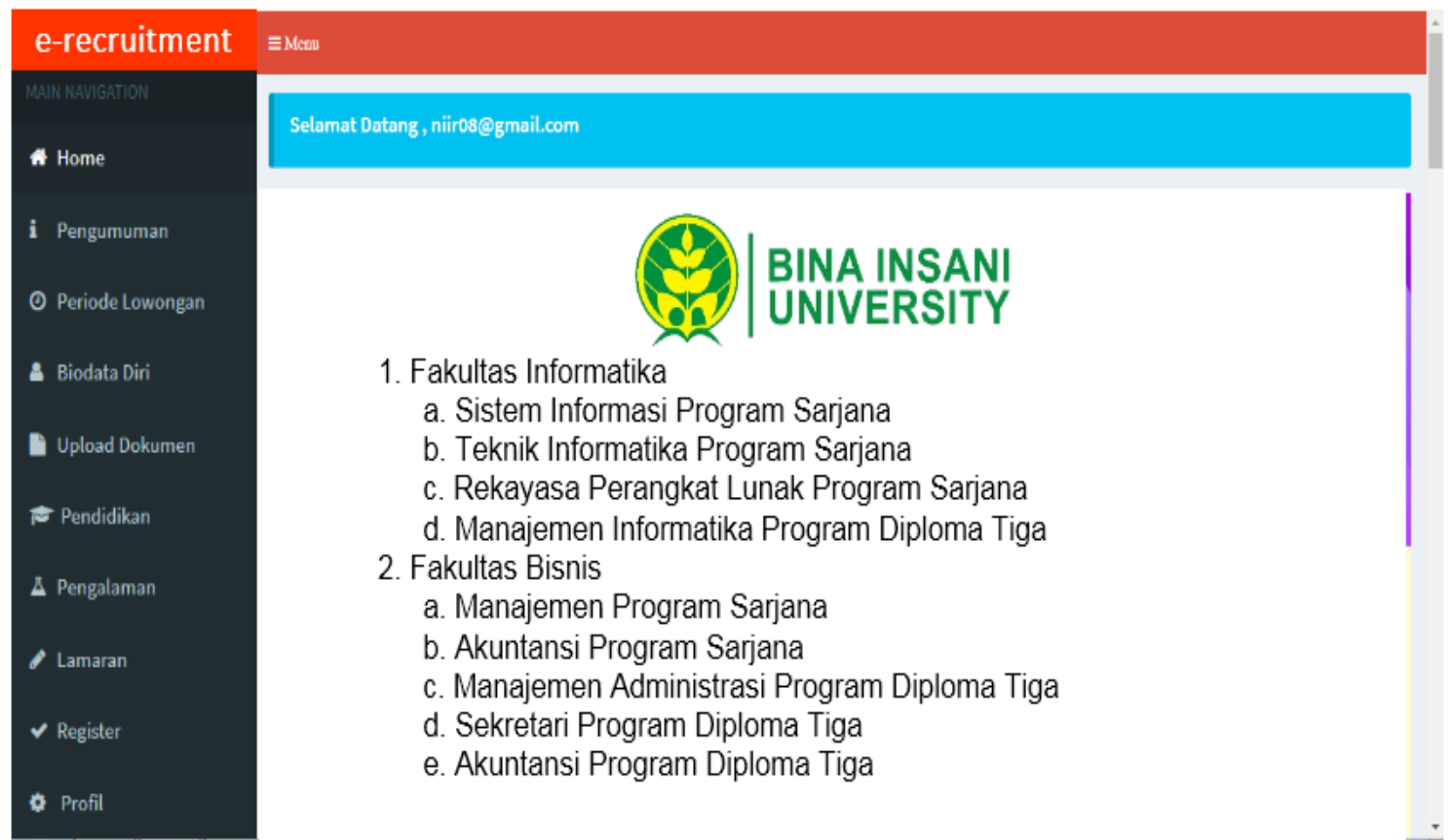

Sumber: Hasil Penelitian (2020)

Gambar 3. Halaman Utama E-Recruitment 
Adapun penjelasan dari halaman utama e-recruitment adalah sebagai berikut: 1) Menu Home untuk menampilkan Selamat Datang kepada pengguna (Dosen Baru). Pengumuman, 2) Menu Pengumuman menampilkan Master Pengumuman yang berisi: no, tanggal post, judul dan aksi (download pengumuman), serta fitur show (10, 25, 50, dan 100) entries dan search, 3) Menu Periode Lowongan untuk menampilkan Periode Lowongan yang berisi no, judul, tanggal dibuka, tanggal ditutup, kontak email dan kontak telepon, aksi (detail lowongan), serta fitur show $(10,25,50$, dan 100) entries dan search, 4) Menu Biodata Diri untuk menampilkan biodata diri yang berisi: gelar depan, gelar belakang, nama lengkap, tempat lahir (pilihan kota/kabupaten), tanggal lahir (yyyy-mm-dd), jenis kelamin (laki-laki atau perempuan), alamat lengkap terdiri dari provinsi, kota/kabupaten, kecamatan, kelurahan/desa, jalan, kode pos, status (PNS atau Non PNS), pangkat akademik (Tenaga Pengajar, Asisten Ahli, Lektor, Lektor Kepala dan Guru Besar), Nomor Induk Dosen Nasional (NIDN) atau Nomor Induk Dosen Khusus (NIDK), Homebase (asal), Nomor Induk Kependudukan (NIK), email, nomor telepon, dan Pendidikan Terakhir (Magister atau Dokter), lalu pilih tombol simpan untuk menyimpan data diri dosen baru dan tombol ubah untuk mengubah data diri dosen baru yang dijelaskan pada gambar 4,5 ) Menu Upload Dokumen berisi petunjuk pengisian: a) setiap pelamar harus melakukan upload dokumen dengan cara menekan tombol upload dan memilih dokumen yang ingin di upload, b) Semua dokumen harus lengkap terupload jika ingin melakukan lamaran, c) Beberapa dokumen memiliki Template, d) File upload berupa PDF, e) Maksimal ukuran file 0,5 Mb. Berikut adalah dokumen yang harus diupload: a) Foto (berwarna background biru, ukuran 4x6, format PDF), b) KTP (Scan KTP Berwarna, format PDF), c) Surat Lamaran, d) Surat Kelakukan Baik, e) Surat Keterangan Sehat Jasmani, f) Surat Keterangan Sehat Rohani, g) Surat Bebas Narkoba, h) Surat Pernyataan Tidak Terlibat Organisasi Terlarang Bermaterai (Download Template), i) Surat Pernyataan Tidak Pernah Dihentikan Secara Tidak Hormat (Download Template). Pada Upload Dokumen berisi no, nama dokumen, jenis dokumen dan aksi (hapus), serta fitur show (10, 25, 50, dan 100) entries dan search, 6) Menu Pendidikan terdiri dari: a) Sub Menu Pendidikan Formal untuk menampilkan Pendidikan Formal dari Dosen Baru yang berisi Pendidikan Terakhir dengan pilihan Sarjana, Magister, dan Dokter.

Pada masing-masing tersebut terdapat fitur tambah yang berisi: nama institusi, alamat institusi, fakultas, program studi, tahun masuk, tahun lulus, Indeks Prestasi Kumulatif (IPK), nomor ijazah, lulusan, upload ijazah asli (scan berwarna, format PDF, file maksimal 0,5 MB), upload transkrip nilai (scan berwarna, format PDF, file maksimal 0,5 MB), upload kesetaraan ijazah untuk universitas luar negeri (scan berwarna, format PDF, file maksimal 0,5 MB), upload akreditasi perguruan tinggi (scan berwarna, format PDF, file maksimal 0,5 MB), dan tombol simpan untuk menyimpan data pendidikan formal untuk sarjana, magister dan doktor serta fitur show (10, 25, 50, dan 100) entries dan search, b) Sub Menu Pendidikan Non Formal untuk menampilkan kursus bahasa, kursus keahlian, tes potensi akademik, TOEIC/TOEFL/IELTS serta fitur show $(10,25,50$, dan 100) entries dan search.

Pada kursus bahasa terdapat fitur tambah yang berisi: institusi, alamat, tahun, nilai/level, penerbit sertifikat dan upload sertifikat (scan berwarna, format PDF, file maksimal 0,5 MB) dan tombol simpan untuk menyimpan data kursus bahasa. Pada kursus keahlian terdapat fitur tambah yang berisi: institusi, alamat, tahun, nilai/level, penerbit sertifikat dan upload sertifikat (scan berwarna, format PDF, file maksimal 0,5 MB) dan tombol simpan untuk menyimpan data kursus keahlian. Pada tes potensi akademis terdapat fitur tambah yang berisi: institusi, alamat, tahun, nilai, penerbit sertifikat dan upload sertifikat (scan berwarna, format PDF, file maksimal 0,5 MB) dan tombol simpan untuk menyimpan data tes potensi akademis.

Pada TOEIC/TOEFL/IELTS terdapat fitur tambah yang berisi: institusi, alamat, tahun, nilai, penerbit sertifikat dan upload sertifikat (scan berwarna, format PDF, file maksimal 0,5 MB) dan tombol simpan untuk menyimpan data TOEIC/TOEFL/IELTS. 7) Menu Pengalaman untuk menampilkan Pengalaman Mengajar Institusi Dalam Negeri dan Luar Negeri, Penelitian, Publikasi Jurnal, Pertemuan IImiah, Pengabdian Masyarakat, Penghargaan, Pengalaman Kerja dan Pengalaman Organisasi.

Pada pengalaman mengajar institusi dalam negeri dan luar negeri terdapat fitur tambah yang berisi: nama institusi, alamat institusi, fakultas, program studi, mata kuliah, lama mengajar, beban sks, upload bukti mengajar (scan berwarna, format PDF, file maksimal 0,5 MB), tombol simpan untuk menyimpan data pengalaman mengajar institusi dalam negeri, fitur show $(10,25$, 50, dan 100) entries dan search. 
Pada pengalaman penelitian terdapat fitur tambah yang berisi: judul penelitian, tahun, lama penelitian (dalam tahun), dana penelitian (rupiah), sumber dana, lokasi penelitian, HKI (Granted, Dalam Proses, Tidak), tombol simpan untuk menyimpan data pengalaman penelitian, fitur show $(10,25,50$, dan 100) entries dan search.

Pada pengalaman publikasi jurnal terdapat fitur tambah yang berisi: level publikasi (pilihan nasional atau internasional), judul, tahun terkait, penerbit, URL jurnal, upload sampul atau editorial (scan berwarna, format PDF, file maksimal 0,5 MB), upload naskah lengkap (scan berwarna, format PDF, file maksimal $0,5 \mathrm{MB}$ ), tombol simpan untuk menyimpan data pengalaman publikasi jurnal, fitur show (10, 25, 50, dan 100) entries dan search.

Pada pengalaman pertemuan ilmiah terdapat fitur tambah yang berisi: nama kegiatan, tahum, tempat, penyelenggara, tingkat (pilihan nasional atau internasional), peran (pembicara, panitia atau peserta), upload sertifikat (scan berwarna, format PDF, file maksimal 0,5 MB), tombol simpan untuk menyimpan pengalaman pertemuan ilmiah, fitur show $(10,25,50$, dan 100) entries dan search.

Pada pengalaman pengabdian masyarakat terdapat fitur tambah yang berisi: nama program, tahun, posisi, periode (dalam tahun), tombol simpan untuk menyimpan pengalaman pengabdian masyarakat, fitur show (10, 25, 50, dan 100) entries dan search. Pada penghargaan terdapat fitur tambah yang berisi: nama penghargaan, tahun, tingkat (pilihan kabupaten/kota, provinsi, nasional atau internasional), upload sertifikat (scan berwarna, format PDF, file maksimal 0,5 MB), tombol simpan untuk menyimpan pengahargaan, fitur show (10, 25, 50, dan 100) entries dan search.

Pada pengalaman kerja terdapat fitur tambah yang berisi: nama institusi, alamat institusi, jabatan, tahun masuk, tahun keluar, tombol simpan untuk menyimpan pengalaman kerja, fitur show $(10,25,50$, dan 100) entries dan search.

Pada pengalaman organisasi terdapat fitur tambah yang berisi: nama institusi, alamat institusi, jabatan (pilihan ketua, wakil ketua, ketua divisi, sekretaris, bendahara, atau staf), tahun, tingkat (pilihan kabupaten/kota, provinsi, nasional atau internasional), tombol simpan untuk menyimpan pengalaman organisasi, fitur show (10, 25, 50, dan 100) entries dan search, 8) Menu Lamaran untuk menampilkan lamaran yang berisi pilihan program studi, tombol simpan untuk menyimpan data lamaran dan tombol ubah untuk mengedit data lamaran, 9) Menu Register untuk melakukan registrasi lamaran kerja dengan menekan tombol Register, catatan: Silahkan Daftar bila yakin sudah melengkapi berkas-berkas yang diperlukan, dan 10) Menu Profil menampilkan ubah password dan keluar aplikasi e-recruitment. Pada ubah password yang terdiri dari password lama, password baru, konfirmasi password baru, dan tombol ubah password untuk mengubah password. Pada keluar aplikasi e-recruitment untuk keluar dari $e$ recruitment.

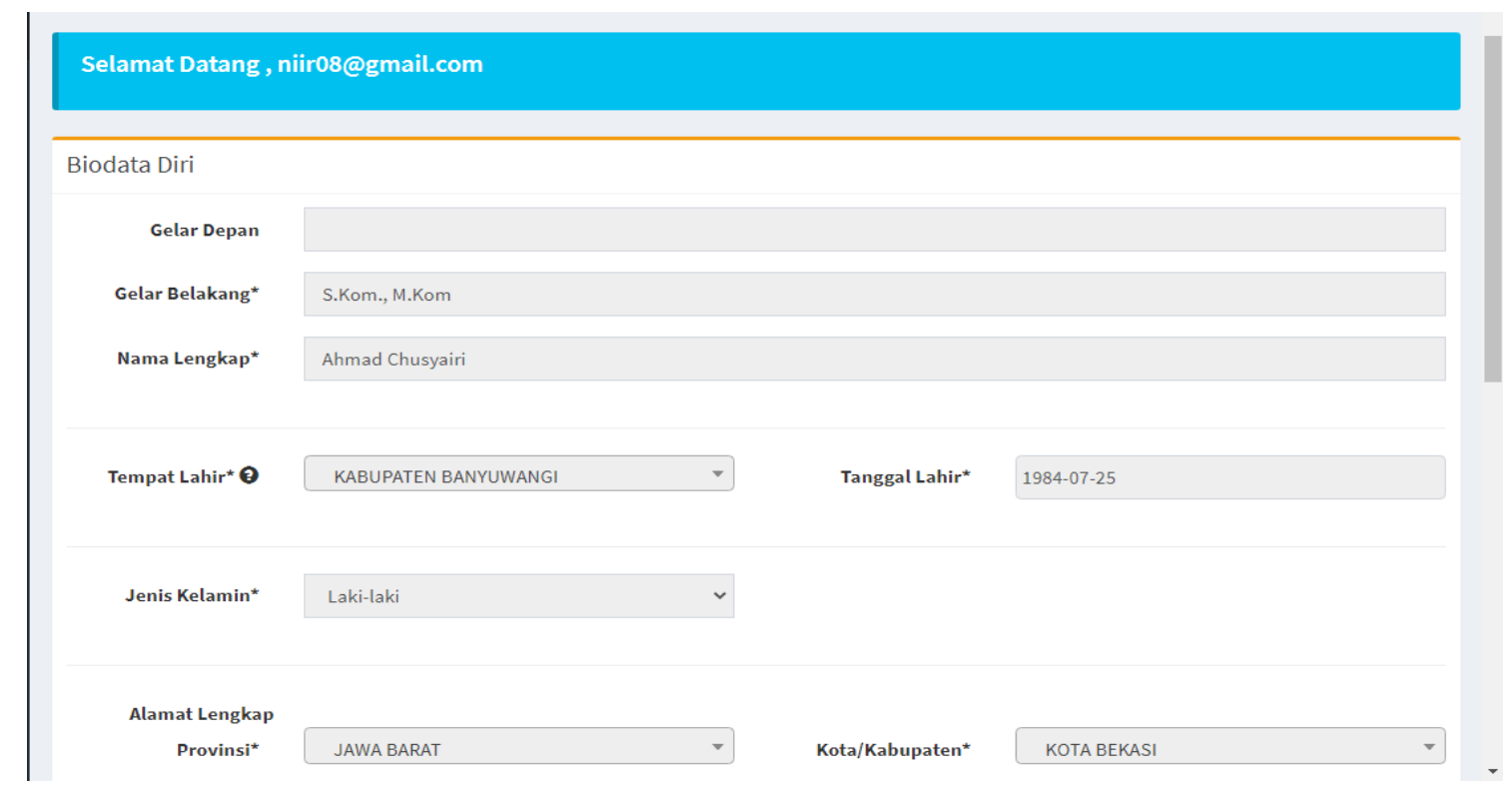

Sumber: Hasil Penelitian (2020)

Gambar 4. Formulir Biodata Diri 
Validate, tahap akhir dengan menguji prototipe e-recruitment yang dibuat. Uji prototipe e-recruitment dilakukan dengan melibatkan user (bidang ketenagaan Universitas Bina Insani) yang dijelaskan pada tabel 1 .

Tabel 1. Pengujian E-Recruitment

\begin{tabular}{|c|c|c|c|}
\hline No & Fitur & Pengujian & Hasil \\
\hline 1 & Menu Home & $\begin{array}{l}\text { Home untuk menampilkan Selamat Datang } \\
\text { kepada pengguna (Dosen Baru) }\end{array}$ & $\begin{array}{l}\text { Berhasil } \\
\text { Tampil }\end{array}$ \\
\hline 2 & Menu Pengumuman & $\begin{array}{l}\text { Menu Pengumuman menampilkan Master } \\
\text { Pengumuman yang berisi: no, tanggal post, } \\
\text { judul dan aksi, serta fitur show entries dan } \\
\text { search. }\end{array}$ & $\begin{array}{l}\text { Berhasil } \\
\text { Tampil }\end{array}$ \\
\hline 3 & $\begin{array}{l}\text { Menu Periode } \\
\text { Lowongan }\end{array}$ & $\begin{array}{l}\text { Menu Periode Lowongan untuk menampilkan } \\
\text { Periode Lowongan yang berisi no, judul, } \\
\text { tanggal dibuka, tanggal ditutup, kontak email } \\
\text { dan kontak telepon, aksi, serta fitur show } \\
\text { entries dan search. }\end{array}$ & $\begin{array}{l}\text { Berhasil } \\
\text { Tampil }\end{array}$ \\
\hline 4 & Menu Biodata Diri & $\begin{array}{l}\text { Menu Biodata Diri untuk menampilkan biodata } \\
\text { diri yang berisi: gelar depan, gelar belakang, } \\
\text { nama lengkap, tempat lahir, tanggal lahir, jenis } \\
\text { kelamin, alamat lengkap terdiri dari provinsi, } \\
\text { kota/kabupaten, kecamatan, kelurahan/desa, } \\
\text { jalan, kode pos, status, pangkat akademik, } \\
\text { NIDN/NIDK, Homebase, NIK, email, nomor } \\
\text { telepon, dan Pendidikan Terakhir, dan tombol } \\
\text { simpan. }\end{array}$ & $\begin{array}{l}\text { Berhasil } \\
\text { Tampil }\end{array}$ \\
\hline 5 & Menu Upload Dokumen & $\begin{array}{l}\text { Menu Upload Dokumen menampilkan no, } \\
\text { nama dokumen, jenis dokumen dan aksi, serta } \\
\text { fitur show entries dan search. }\end{array}$ & $\begin{array}{l}\text { Berhasil } \\
\text { Tampil }\end{array}$ \\
\hline 6 & $\begin{array}{l}\text { Sub Menu Pendidikan } \\
\text { Formal }\end{array}$ & $\begin{array}{l}\text { Sub Menu Pendidikan Formal untuk } \\
\text { menampilkan Pendidikan Formal dari Dosen } \\
\text { Baru yang berisi Pendidikan Terakhir. Pada } \\
\text { masing-masing tersebut terdapat fitur tambah } \\
\text { yang berisi: nama institusi, alamat institusi, } \\
\text { fakultas, program studi, tahun masuk, tahun } \\
\text { lulus, IPK, nomor ijazah, lulusan, upload ijazah } \\
\text { asli, upload transkrip nilai, upload kesetaraan } \\
\text { ijazah untuk universitas luar negeri (scan } \\
\text { berwarna, format PDF, upload akreditasi } \\
\text { perguruan tinggi, dan tombol simpan untuk } \\
\text { menyimpan data pendidikan formal serta fitur } \\
\text { show entries dan search. }\end{array}$ & $\begin{array}{l}\text { Berhasil } \\
\text { Tampil }\end{array}$ \\
\hline 7 & $\begin{array}{l}\text { Sub Menu Pendidikan } \\
\text { Non Formal (Kursus } \\
\text { Bahasa) }\end{array}$ & $\begin{array}{l}\text { Sub Menu Pendidikan Non Formal (Kursus } \\
\text { Bahasa) menampilkan fitur tambah yang } \\
\text { berisi: institusi, alamat, tahun, nilai/level, } \\
\text { penerbit sertifikat dan upload sertifikat dan } \\
\text { tombol simpan untuk menyimpan data kursus } \\
\text { bahasa. }\end{array}$ & $\begin{array}{l}\text { Berhasil } \\
\text { Tampil }\end{array}$ \\
\hline 8 & $\begin{array}{l}\text { Sub Menu Pendidikan } \\
\text { Non Formal (Kursus } \\
\text { Keahlian) }\end{array}$ & $\begin{array}{l}\text { Sub Menu Pendidikan Non Formal (Kursus } \\
\text { Keahlian) menampilkan fitur tambah yang } \\
\text { berisi: institusi, alamat, tahun, nilai/level, } \\
\text { penerbit sertifikat dan upload sertifikat dan } \\
\text { tombol simpan untuk menyimpan data kursus } \\
\text { keahlian. }\end{array}$ & $\begin{array}{l}\text { Berhasil } \\
\text { Tampil }\end{array}$ \\
\hline 9 & $\begin{array}{l}\text { Sub Menu Pendidikan } \\
\text { Non Formal (Tes } \\
\text { Potensi Akademis) }\end{array}$ & $\begin{array}{l}\text { Sub Menu Pendidikan Non Formal (Tes } \\
\text { Potensi Akademis) menampilkan fitur tambah } \\
\text { yang berisi: institusi, alamat, tahun, nilai, } \\
\text { penerbit sertifikat dan upload sertifikat dan } \\
\text { tombol simpan untuk menyimpan data tes } \\
\text { potensi akademis. }\end{array}$ & $\begin{array}{l}\text { Berhasil } \\
\text { Tampil }\end{array}$ \\
\hline 10 & $\begin{array}{l}\text { Sub Menu Pendidikan } \\
\text { Non Formal } \\
\text { (TOEIC/TOEFL/IELTS) }\end{array}$ & $\begin{array}{l}\text { Sub Menu Pendidikan Non Formal } \\
\text { (TOEIC/TOEFL/IELTS) menampilkan fitur } \\
\text { tambah yang berisi: institusi, alamat, tahun, } \\
\text { nilai, penerbit sertifikat dan upload sertifikat } \\
\text { dan tombol simpan untuk menyimpan data } \\
\text { TOEIC/TOEFL/IELTS }\end{array}$ & $\begin{array}{l}\text { Berhasil } \\
\text { Tampil }\end{array}$ \\
\hline 11 & $\begin{array}{l}\text { Sub Menu Pengalaman } \\
\text { Mengajar Institusi } \\
\text { Dalam Negeri }\end{array}$ & $\begin{array}{l}\text { Sub Menu Pengalaman Mengajar Institusi } \\
\text { Dalam Negeri menampilkan fitur tambah yang } \\
\text { berisi: nama institusi, alamat institusi, fakultas, } \\
\text { program studi, mata kuliah, lama mengajar, }\end{array}$ & $\begin{array}{l}\text { Berhasil } \\
\text { Tampil }\end{array}$ \\
\hline
\end{tabular}




\begin{tabular}{|c|c|c|c|}
\hline No & Fitur & Pengujian & Hasil \\
\hline & & $\begin{array}{l}\text { beban sks, upload bukti mengajar, tombol } \\
\text { simpan untuk menyimpan data pengalaman } \\
\text { mengajar institusi dalam negeri, fitur show } \\
\text { entries dan search. }\end{array}$ & \\
\hline 12 & $\begin{array}{l}\text { Sub Menu Pengalaman } \\
\text { Mengajar Institusi Luar } \\
\text { Negeri }\end{array}$ & $\begin{array}{l}\text { Sub Menu Pengalaman Mengajar Institusi } \\
\text { Luar Negeri menampilkan fitur tambah yang } \\
\text { berisi: nama institusi, alamat institusi, fakultas, } \\
\text { program studi, mata kuliah, lama mengajar, } \\
\text { beban sks, upload bukti mengajar, tombol } \\
\text { simpan untuk menyimpan data pengalaman } \\
\text { mengajar institusi dalam negeri, fitur show } \\
\text { entries dan search. }\end{array}$ & $\begin{array}{l}\text { Berhasil } \\
\text { Tampil }\end{array}$ \\
\hline 13 & $\begin{array}{l}\text { Sub Menu Pengalaman } \\
\text { Penelitian }\end{array}$ & $\begin{array}{l}\text { Sub Menu Pengalaman Penelitian } \\
\text { menampilkan fitur tambah yang berisi: judul } \\
\text { penelitian, tahun, lama penelitian (dalam } \\
\text { tahun), dana penelitian (rupiah), sumber dana, } \\
\text { lokasi penelitian, HKI, tombol simpan untuk } \\
\text { menyimpan data pengalaman penelitian, fitur } \\
\text { show entries dan search. }\end{array}$ & $\begin{array}{l}\text { Berhasil } \\
\text { Tampil }\end{array}$ \\
\hline 14 & $\begin{array}{l}\text { Sub Menu Pengalaman } \\
\text { Publikasi Jurnal }\end{array}$ & $\begin{array}{l}\text { Sub Menu Pengalaman Publikasi Jurnal } \\
\text { menampilkan fitur tambah yang berisi: level } \\
\text { publikasi, judul, tahun terkait, penerbit, URL } \\
\text { jurnal, upload sampul atau editorial, upload } \\
\text { naskah lengkap, tombol simpan untuk } \\
\text { menyimpan data pengalaman publikasi jurnal, } \\
\text { fitur show entries dan search. }\end{array}$ & $\begin{array}{l}\text { Berhasil } \\
\text { Tampil }\end{array}$ \\
\hline 15 & $\begin{array}{l}\text { Sub Menu Pengalaman } \\
\text { Pertemuan IImiah }\end{array}$ & $\begin{array}{l}\text { Sub Menu Pengalaman Pertemuan Ilmiah } \\
\text { menampilkan fitur tambah yang berisi: nama } \\
\text { kegiatan, tahum, tempat, penyelenggara, } \\
\text { tingkat, peran, upload sertifikat, tombol simpan } \\
\text { untuk menyimpan pengalaman pertemuan } \\
\text { ilmiah, fitur show entries dan search. }\end{array}$ & $\begin{array}{l}\text { Berhasil } \\
\text { Tampil }\end{array}$ \\
\hline 16 & $\begin{array}{l}\text { Sub Menu Pengalaman } \\
\text { Pengabdian } \\
\text { Masyarakat }\end{array}$ & $\begin{array}{l}\text { Sub Menu Pengalaman Pengabdian } \\
\text { Masyarakat menampilkan fitur tambah yang } \\
\text { berisi: nama program, tahun, posisi, periode } \\
\text { (dalam tahun), tombol simpan untuk } \\
\text { menyimpan pengalaman pengabdian } \\
\text { masyarakat, fitur show entries dan search. }\end{array}$ & $\begin{array}{l}\text { Berhasil } \\
\text { Tampil }\end{array}$ \\
\hline 17 & $\begin{array}{l}\text { Sub Menu } \\
\text { Penghargaan }\end{array}$ & $\begin{array}{l}\text { Sub Menu Penghargaan menampilkan fitur } \\
\text { tambah yang berisi: nama penghargaan, } \\
\text { tahun, tingkat, upload sertifikat, tombol simpan } \\
\text { untuk menyimpan pengahargaan, fitur show } \\
\text { entries dan search. }\end{array}$ & $\begin{array}{l}\text { Berhasil } \\
\text { Tampil }\end{array}$ \\
\hline 18 & $\begin{array}{l}\text { Sub Menu Pengalaman } \\
\text { Kerja }\end{array}$ & $\begin{array}{l}\text { Sub Menu Pengalaman Kerja menampilkan } \\
\text { fitur tambah yang berisi: nama institusi, alamat } \\
\text { institusi, jabatan, tahun masuk, tahun keluar, } \\
\text { tombol simpan untuk menyimpan pengalaman } \\
\text { kerja, fitur show entries dan search. }\end{array}$ & $\begin{array}{l}\text { Berhasil } \\
\text { Tampil }\end{array}$ \\
\hline 19 & $\begin{array}{l}\text { Sub Menu Pengalaman } \\
\text { Organisasi }\end{array}$ & $\begin{array}{l}\text { Sub Menu Pengalaman Organisasi } \\
\text { menampilkan fitur tambah yang berisi: nama } \\
\text { institusi, alamat institusi, jabatan, tahun, } \\
\text { tingkat, tombol simpan untuk menyimpan } \\
\text { pengalaman organisasi, fitur show entries dan } \\
\text { search. }\end{array}$ & $\begin{array}{l}\text { Berhasil } \\
\text { Tampil }\end{array}$ \\
\hline 20 & Menu Lamaran & $\begin{array}{l}\text { Menu Lamaran untuk menampilkan lamaran } \\
\text { yang berisi pilihan program studi, tombol } \\
\text { simpan untuk menyimpan data lamaran dan } \\
\text { tombol ubah untuk mengedit data lamaran. }\end{array}$ & $\begin{array}{l}\text { Berhasil } \\
\text { Tampil }\end{array}$ \\
\hline 21 & Menu Register & $\begin{array}{l}\text { Menu Register untuk melakukan registrasi } \\
\text { lamaran kerja dengan menekan tombol } \\
\text { Register, catatan: Silahkan Daftar bila yakin } \\
\text { sudah melengkapi berkas-berkas yang } \\
\text { diperlukan. }\end{array}$ & $\begin{array}{l}\text { Berhasil } \\
\text { Tampil }\end{array}$ \\
\hline 22 & $\begin{array}{l}\text { Sub Menu Ubah } \\
\text { Password }\end{array}$ & $\begin{array}{l}\text { Sub Menu Ubah Password menampilkan } \\
\text { password lama, password baru, konfirmasi } \\
\text { password baru, dan tombol ubah password } \\
\text { untuk mengubah password }\end{array}$ & $\begin{array}{l}\text { Berhasil } \\
\text { Tampil }\end{array}$ \\
\hline
\end{tabular}

Sumber: Hasil Penelitian (2020) 
Berdasarkan hasil testing dapat dilihat bahwa seluruh fungsi telah diuji oleh pengguna dan menghasilkan hasil yang baik yaitu secara keseluruhan fungsi yang terdapat pada aplikasi dapat difungsikan sesuai dengan kebutuhan diawal. Dengan kata lain bahwa aplikasi yang dibangun dalam hal membantu dalam proses rekrutmen dosen baru dapat berjalan dan dapat diterapkan di Universitas Bina Insani.

\section{Kesimpulan}

Kesimpulan yang didapatkan dalam penelitian ini adalah kemudahan dalam perekrutan dosen baru untuk ditempatkan pada program studi: S1-Teknik Informatika, S1-Sistem Informasi, S1-Rekayasa Perangkat Lunak, S1-Akuntansi, S1-Manajemen, D3-Manajemen Informatika, D3Akuntansi, D3-Manajemen Administrasi, dan D3-Sekretari yang ada di Universitas Bina Insani. Perancangan E-Recruitment Dosen Baru Berbasis Web. Metode design sprint dengan tahapan understanding, diverage, decide, prototype dan validate dapat memudahkan dalam Perancangan E-Recruitment Dosen Baru Berbasis Web.

\section{Ucapan Terima Kasih}

Peneliti mengucapkan banyak terima kasih kepada Universitas Bina Insani yang telah memberikan dukungan selama berjalannya kegiatan penelitian.

\section{Referensi}

[1] L. P. I. Kharisma, "Sistem Pendukung Keputusan untuk Seleksi Penerimaan Dosen menggunakan Metode AHP dan SAW," Jurnal Teknologi Informasi dan Multimedia, vol.1, no.2, pp.160-165, 2019.

[2] H. Asnai and F. Zoromi, "Penerapan Metode Multi Utility Theory dalam Sistem Seleksi Penerimaan Dosen di STMIK-AMIK-Riau," Rabit: Jurnal Teknologi dan Sistem Informasi Univrab, vol 5, no. 1, pp. 44-53, 2020.

[3] J. D. Raharjo and A. Darmadi, "Sistem Penunjang Keputusan Penerimaan Dosen dengan Metode Analytic Hierarchy Process," Jurnal Sisfotek Global, vol. 5, no. 1, pp. 49-54, 2015.

[4] F. Wahyudi and S. Utama, "Sistem Pendukung Keputusan Penerimaan Dosen Baru menggunakan Metode Profile Matching (Studi Kasus: Universitas Islam Raden Rahmat Malang)," Jurnal Teknologi Terapan G-Tech, vol. 3, no. 1, pp. 168-174, 2019.

[5] N. Hidayati, "Analisa Penerimaan Dosen Baru dengan menggunakan SAW (Simple Additive Weighting)," Jurnal Transformatika, vol. 14, no. 1, pp. 12-17, 2016.

[6] Ikmah, Kusrini and A. Sunyoto, "Sistem Pendukung Keputusan Seleksi Penerimaan Dosen di STMIK Amikom Yogyakarta menggunakan Metode Topsis dan Borda," Jurnal Telematika, vol. 10, no. 2, pp. 44-61, 2017.

[7] D. Winarso and E. Arribe, "Seleksi Pegawai dan Dosen UMRI Berbasis E-Recruitment menggunakan Metode K-Nearest Neighbor," Jurnal Teknologi Informasi \& Komunikasi Digital Zone, vol. 8, no. 2, pp. 71-80, 2017.

[8] R. Ramadan, H. M. Az-Zahra and R. I. Rokhmawati, "Perancangan User Interface Aplikasi EzyPay menggunakan metode Design Sprint (Studi Kasus PT. Arta Elektronik Indonesia)," Jurnal Pengembangan Teknologi Informasi dan Komputer, vol. 3, no. 9, pp. 8831-8840, 2019.

[9] N. I. Wijayanti, R. Yulianti and B. Wijaya, "Perancangan Chat Bot Messenger dengan Pendekatan User Centered Design (Studi Kasus: Perpustakaan Fakultas Teknik Universitas UGM)," Media Pustakawan, vol. 26, no. 4, pp. 254-267, 2019.

[10] J. Knapp, J. Zeratsky and B. Kowitz, Sprint How to Solve Big Problems and Test New Ideas in Just Five Days. San Francisco: Simon \& Schuster eBook, 2016.

[11] H. A. P. Wendri, J. D. Irawan and A. Faisol, "Penerapan Location Based Service untuk Pencarian Lokasi Rapat Menggunakan Metode Design Sprint," Jurnal Mahasiswa Teknik Informatika: JATI, vol. 4, no. 2, pp. 144-149, 2020.

[12] Baket, Pedoman Sumber Daya Manusia Universitas. Bekasi: Universitas Bina Insani, 2020.

[13] A. Chusyairi, D. Setiyadi, Saludin and U. Rusmawan, "PkM Pengenalan Online PHP dengan $\mathrm{Cl}$ untuk ASN dan Non ASN Pemerintah Kota Bekasi," Caradde: Jurnal Pengabdian Kepada Masyarakat, vol. 3, no. 1, pp. 166-173, 2020.

[14] A. Chusyairi, "Pengembangan Web Kependudukan Desa Grogol Banyuwangi Dengan Metode MVC," Jurnal Teknologi Informasi (JTI), vol. 13, no. 3, pp.1-6, 2017. 
[15] A. Chusyairi \& M. Y. Usman, "Pengembangan Web Pelayanan Publik Polres Banyuwangi Dengan Metode MVC," in Prosiding Seminar Nasional Teknologi Informasi dan Multimedia (Semnas Teknomedia). pp.1.2-115-1.2-120. Yogyakarta: STMIK Amikom Yogyakarta, 2017. 